\title{
APRESENTAÇÃO - DOSSIÊ RAWLS
}

A edição especial da Revista Dissertatio pretende refletir sobre a importância da filosofia moral e política de John Rawls no cenário filosófico atual no ano em que sua obra mais conhecida, A Theory of Justice (T), completa quarenta anos. Esta data comemorativa é apenas um pretexto para uma avaliação integral do projeto de Rawls, o que inclui obras posteriores, como, por exemplo, Political Liberalism (PL) e The Law of Peoples (LP). Os artigos aqui reunidos procuram tematizar tanto a estrutura quanto o conteúdo da teoria da justiça como equidade (justice as fairness), avaliando atentamente as suas virtudes e, também, as suas fraquezas.

Originalmente publicada em 1971, e já traduzida para mais de trinta idiomas, TJ rapidamente se constituiu em um dos marcos filosóficos da segunda metade do século vinte ao procurar construir uma teoria moral normativa de forma independente das investigações em epistemologia, ontologia, filosofia da mente e teoria do significado, isto é, prioritária em relação às investigações metaéticas que eram hegemônicas até a primeira metade do século vinte, propondo uma forma diferenciada de justificação do critério de justiça (fairness - equidade) para sociedades plurais e democráticas. Ao recusar um modelo fundacionalista de justificação, como o cartesiano, utilitarista, intuicionista, naturalista ou perfeccionista, Rawls adota um modelo coerentista de justificação, conectado às propostas de Wittgenstein, Goodman, Quine e White, defendendo que a natureza da justificação se encontra no consenso. Isto corresponde à estrutura da teoria da justiça como equidade, em que os procedimentos da posição original, equilíbrio reflexivo e, mais tarde, consenso sobreposto, são chaves para se compreender a proposta construtivista e coerentista de Rawls.

No que diz respeito ao conteúdo, Rawls propõe uma co-originalidade entre liberdade e igualdade, defendendo uma concepção igualitarista de justiça que respeita a individualidade, propondo dois princípios de justiça que se pretendem superiores ao princípio da utilidade ao assegurar (i) igual liberdade e (ii) igualdade equitativa de oportunidade e respeito à diferença. 
Este conteúdo contrasta fortemente com a proposta libertariana, que defende puramente a liberdade individual, bem como contrasta com uma proposta igualitarista, que se centra basicamente nos direitos públicos. Importante ressaltar que a justiça como equidade quer ser uma alternativa ao modelo utilitarista de justiça que opera com a maximização do bem-estar ou preferências, evitando o princípio do sacrifício, por exemplo, ao partir da ideia central da sociedade como um sistema equitativo de cooperação social, o que implica tomar a pessoa e a sociedade como morais (em um sentido político).

Mas haveria uma contraposição no projeto rawlsiano no que diz respeito à concepção de justiça apresentada em $T J$ e $P L$, a saber, uma contraposição de uma concepção normativa kantiana com outra concepção contextualista de justiça? Catherine Audard defende a coerência da teoria da justiça como equidade considerando as duas obras. Diz que a concepção política de justiça que se baseia no princípio de tolerância e favorece a estabilidade social é melhor compreendida em proximidade com a filosofia prática kantiana, sendo o 'político' entendido como um puro poder prático, autônomo em relação à razão pura teórica, que reconcilia autonomia doutrinal e completa e se afasta do intuicionismo racional. Percy B. Lehning também defende a coerência e unidade do projeto rawlsiano ao abordar um elemento central da concepção de justiça igualitária, a saber, a forma das estruturas institucionais das sociedades em paralelo com o que é exigido pela justiça como equidade. Mesmo não diretamente ligado à Rawls, o texto de Christine Korsgaard esclarece sobre a concepção de razão prática como uma consideração normativamente motivadora a partir de Aristóteles e Kant, o que possibilita uma melhor compreensão da concepção de razão prática usada por Rawls.

De forma estrita, a justiça como equidade pode ser classificada como uma teoria moral normativa, pois propõe dois princípios morais-políticos para regular a estrutura básica da sociedade. Isto é apenas meia verdade, pois esta teoria tem como um de seus principais focos oferecer um modelo de construção e justificação para os princípios morais, bem como para a justificação dos juízos morais e para as diversas crenças dos indivíduos. Isto parece indicar que ela também pode ser avaliada por suas contribuições metaéticas que, evidentemente, não estariam desconectadas de um âmbito prático, pois justificação, para Rawls, é uma questão prática. Sobre esta questão, Denilson Werle aponta para o entrelaçamento da justificação 
pública dos princípios de justiça e o procedimento democrático de legitimação política, ao procurar responder às críticas que acusam Rawls de estabelecer uma prioridade da autonomia privada sobre a pública, o que revela uma forma de conceber a justificação como complementar ao problema da legitimação. Também, Denis Silveira interpreta a teoria da justiça de Rawls como um sistema coerentista de justificação, uma vez que “justificação é uma questão de apoio mútuo de várias considerações, todas harmonizadas em conjunto em uma concepção coerente” (TJ IX, § 87: 579/507 rev.), que conta com uma epistemologia coerentista holística, uma teoria do contrato social que introduz uma ontologia social e uma estratégia pragmatista na teoria contratualista, integrando justificação e legitimação.

Mesmo não tratando especificamente de problemas práticos da ética, é possível perguntar em que medida esta teoria pode contribuir com a investigação dos problemas de ética prática. É o que faz Darlei Dall'Agnol ao discutir as possíveis contribuições do procedimento do equilíbrio reflexivo na bioética, analisando seu alcance e seus limites. Para tal, reconstrói as características do método feitas por Rawls em $T J$ e $P L$; aponta para as distinções entre equilíbrio reflexivo estreito (narrow) e amplo (wide); analisa as aplicações feitas por Rawls na discussão sobre eugenia e aborto e, por fim, aborda o uso do método feito por Daniels e Beauchamp and Childress. Esta é uma forma interessante de ressaltar a força do modelo justificacional coerentista adotado por Rawls em seu projeto filosófico.

Outra observação relevante é que a teoria da justiça como equidade pretende superar diversas dicotomias, a saber, dicotomia entre direito e moral, entre política e religião, entre moral e economia e entre liberdade e igualdade. Por exemplo, defende uma posição não positivista ao reivindicar uma orientação moral ao direito, sem, entretanto, reduzir o direito à esfera moral e, também, defende uma concepção de liberdade que integra aspectos positivos e negativos e uma concepção inclusivista de razão pública. Este ponto de vista de superação de dicotomias é assumido nos artigos seguintes. Delamar Volpato Dutra e Marcos Rohling abordam a relação entre direito e moral em Rawls, identificando que o Direito deve ser orientado pelos princípios de justiça, os quais, pela administração regular da justiça, fazem surgir o estado de direito que possui a função de defender as liberdades básicas, afastando-se tanto de um modelo positivista como o de Kelsen e Hart quanto do jusnaturalismo processual de Fuller. Cesar Augusto Ramos analisa a concepção de liberdade de Rawls que está vinculada a uma 
concepção de pessoa, integrando a liberdade negativa e positiva. Ele aponta para a concepção de liberalismo político como um tipo diferenciado de liberalismo em razão de buscar hegelianamente uma reconciliação da racionalidade do mundo com a realidade social e política dos indivíduos, tomando como complementares o valores de liberdade e igualdade. Alcino Bonella ressalta o aspecto igualitário do liberalismo político de Rawls, mostrando que o verdadeiro primeiro princípio da justiça como equidade não é o princípio das liberdades iguais e que o princípio da diferença possui um caráter rigorosamente igualitarista. Luiz Bernardo Araujo destaca o interesse de Rawls pela relação entre religião e política, resultando em uma concepção inclusivista mitigada de razão pública presente no liberalismo político ao interconectar os valores religiosos e seculares na justificação pública, não tratando da religião e da política em duas esferas distintas. Carlos Ferraz analisa o projeto kantiano de $A$ Paz Perpétua como uma base importante para o direito dos povos que é proposto por Rawls em $L P$, identificando semelhanças e diferenças nos projetos, ressaltando uma semelhança na distinção entre "Povos e "Estados" e uma proximidade do conceito de razão pública e uso público da razão.

Certamente este dossiê não pretende fazer um balanço conclusivo do legado do pensamento rawlsiano. É verdade que $T J$ e, também, $P L$ e $L P$ marcaram consideravelmente a filosofia moral e política do século vinte, sendo também importantes para as áreas do direito, economia e política, por exemplo. Entretanto, o mais relevante desta teoria moral são as respostas que ainda podem ser pensadas para a resolução de certos problemas que são abordados pelo pensamento contemporâneo. Nesse sentido, TJ é ainda uma obra em progresso.

Denis Coitinho Silveira

Verão 2011 